\title{
A construção metafórica e metonímica da anarquia na história em quadrinhos $\mathbf{V}$ de Vingança
}

\author{
The metaphorical and metonymic construction of anarchy in $V$ de Vingança comics
}

\section{Ada Lima Ferreira de Sousa}

Universidade Federal do Rio Grande do Norte - UFRN - Rio Grande do Norte - Brasil

\begin{abstract}
$\longrightarrow$
Resumo: O objetivo deste artigo é evidenciar a construção metafórica e metonímica do domínio da anarquia durante a leitura da história em quadrinhos $\mathrm{V}$ de Vingança (MOORE; LLOYD, 2006). Para tanto, ancoramo-nos nos conceitos de metáfora (LAKOFF; JOHNSON, [1980]2003; 1999) e metonímia (BARCELONA, 2003; KÖVECSES, 2004) situados no arcabouço teórico da Linguística Cognitiva. A análise, de natureza qualitativa, é aplicada a fragmentos da referida obra a partir dos quais foi possível construir metáforas e metonímias ancoradas, concomitantemente, no texto verbal e nos recursos gráficos. A análise evidencia a metáfora ANARQUIA É ESPETÁCULO TEATRAL, ancorada, particularmente, na metonímia PARTE PELO TODO. Entendemos que os resultados reforçam tanto a ideia de motivação metonímica das construções metafóricas quanto a compreensão de que investigar esse fenômeno nos permite acessar visões de mundo, as quais podem se revelar a partir da leitura integrada de distintas modalidades.
\end{abstract}

Palavras-chave: V de Vingança. Metáfora. Metonímia. Multimodalidade. Linguística Cognitiva.

Abstract: This article aims to demonstrate the metaphorical and metonymic construction of the domain of anarchy during the reading of the comics $\mathrm{V}$ de Vingança (MOORE; LLOYD, 2006). For this purpose, we are anchored in the concepts of metaphor (LAKOFF; JOHNSON, [1980]2003; 1999) and metonymy (BARCELONA, 2003; KÖVECSES, 2004) that are present in the theoretical framework of Cognitive Linguistics. Qualitative analysis was applied to passages of the comics from which it was possible to build metaphors and metonymies based in verbal and graphical texts simultaneously. As a result, the analysis highlights the metaphor ANARCHY IS THEATRAL SPECTACLE that is particularly anchored in the metonymy PART FOR WHOLE. The results reinforce both the idea of metonymic motivation of metaphorical constructions and the comprehension that investigating this phenomenon allows us to access worldviews, which can be revealed through the integrated reading of different modalities.

Keywords: V de Vingança. Metonymy. Metaphor. Multimodality. Cognitive Linguistics. 


\section{Introdução}

Metáforas e metonímias vêm sendo discutidas desde a época dos gregos antigos, quando eram vistas necessariamente como tropos linguísticos. Hoje, vertentes dos estudos da linguagem, a exemplo da Linguística Cognitiva, consideram que elas devem ser tomadas não como recursos retóricos, mas, principalmente, como fenômenos que revelam importantes aspectos das nossas práticas linguísticas cotidianas e da maneira como percebemos o mundo à nossa volta. Uma vez que é por meio da linguagem que elas se manifestam, encontramos, nas mais diversas práticas discursivas, pistas de como tais constructos se configuram a partir das nossas experiências corpóreas e sociais mais básicas.

Com base nessa compreensão, propomo-nos, neste artigo, a tecer considerações sobre a construção metafórica e metonímica em um fragmento da história em quadrinhos $V$ de vingança. A escolha desse corpus é motivada pelo fato de ser uma narrativa multimodal, que podemos, a partir dela, fazer considerações sobre a leitura integrada de texto verbal e de recursos não verbais, além de evidenciar como, em textos multimodais, pode-se identificar metáforas e metonímias que indicam certas visões de mundo.

Considerando o objetivo deste artigo, antes de proceder à análise do corpus, apresentaremos algumas considerações sobre o aparato teórico que fundamenta nossa discussão e, na sequência, comentários sobre $V$ de vingança e os procedimentos de análise.

\section{Metáfora}

De acordo com Lakoff e Johnson ([1980]2003), construir uma metáfora é compreender uma experiência em termos de outra. Em termos cognitivos, segundo os autores, essas experiências se organizam na forma de domínios e, entre eles, se estabelece a seguinte relação: um, o domínio-alvo, é conceptualizado a partir de atributos do outro, o domínio-fonte. Assim, quando formulamos sentenças como ele atacou os pontos fracos da minha argumentação e suas afirmações são indefensáveis, isso indica que pensamos no domínio discussão em termos do domínio guerra. Entre eles, ocorrem mapeamentos, ou seja, relações entre alguns elementos de ambos os domínios, de maneira que estabelecemos a metáfora DISCUSSÃO É GUERRA ${ }^{1}$.

Lakoff e Johnson reforçam que não se trata apenas de nos referirmos a uma experiência em termos de outra, mas de construir todo um sistema conceptual envolvendo essas experiências. Assim, em se tratando da metáfora DISCUSSÃO É GUERRA, estabelecemos relações de modo a pensarmos no interlocutor como um oponente; escolhemos estratégias de argumentação para defendermos um ponto de vista e derrubarmos o do interlocutor; e assim por diante. Essas escolhas se pautam em uma concepção construída a partir das interações cotidianas com 0 ambiente em que vivemos, com as pessoas com quem nos comunicamos e com a cultura em que estamos imersos.

Esse entendimento é expandido quando Lakoff e Johnson (1999) adotam uma abordagem de cunho mais neural, posto que os domínios da experiência passam a ser pensados, de fato, como estruturas cognitivamente situadas e decorrentes de ativações neuronais, o que deu à teoria uma abordagem mais corporificada.

Nesse sentido, os autores mencionam as metáforas primárias, que se caracterizam pela coativação neural de domínios de experiências básicas. Por exemplo, a metáfora AFETO É CALOR, subjacente a expressões como nosso relacionamento esfriou, configura-se a partir da ativação concomitante da rede neural ligada à percepção de afeto e da que se relaciona à percepção de calor. Ambas apontam diretamente para uma experiência sensório-motora básica, vivenciada desde quando, ainda bebês, somos aconchegados no colo de alguém e experienciamos, concomitantemente, o afeto que nos é dedicado e a elevação da temperatura em

\footnotetext{
1 A convenção de grafar metáforas e metonímias em letras maiúsculas é adotada por Lakoff e Johnson ([1980]2003) e preservada neste artigo.
} 
decorrência do contato entre os corpos. À medida que a experiência - e, consequentemente, a ativação das redes neuronais - se repete, a ligação entre os domínios vai se automatizando a ponto de as expressões metafóricas emergirem na linguagem. Tais metáforas, por terem relação direta com nosso aparato sensório-motor e perceptual, apontam para a existência de aspectos universais da corporalidade e, por conseguinte, da cognição humana.

Há ainda, entre as metáforas, as que se classificam como complexas. Trata-se daquelas que apontam para um aspecto mais relativizado da cognição humana, pois se fundamentam em vivências sociais e culturais. Pensemos, por exemplo, nas sentenças preciso ganhar tempo; cada minuto é precioso para nós, entre outras. Fazemos essas analogias porque vivemos em uma cultura na qual o trabalho é associado ao tempo que a ele dedicamos, e costumamos quantificar esse tempo em horas, semanas, dias e/ou meses ao longo dos quais prestamos serviços em troca de retribuição pecuniária. Assim, costumamos pensar no tempo como um recurso limitado usado para cumprir metas e como uma mercadoria valiosa que pode ser usada, gasta, bem ou mal investida, entre outras aplicações comuns ao domínio dinheiro. Assim se estrutura a metáfora TEMPO É DINHEIRO, na qual há dois conceitos distintos que evocam não uma experiência primária, mas dois domínios distintos, mapeados concomitantemente de modo a formar uma metáfora característica das sociedades industrializadas e capitalistas. Trata-se, portanto, de uma metáfora não universal, embora haja, em sua base, a ativação de estruturas universais; o que ocorre é que tais estruturas são ativadas de maneiras diferentes, a depender dos aspectos culturais.

Com base nessa explanação, percebemos que, quando ocorre o mapeamento metafórico, selecionamos apenas alguns entre todos os atributos que podem compor um domínio. Essa focalização de parte dos aspectos mapeados permite concluir que, subjacente à metáfora, existe a metonímia, sobre a qual discorreremos na próxima sessão.

\section{Metonímia}

A exemplo do que ocorre com a metáfora, a metonímia também é ativada por pistas linguísticas, tem contrapartida corpórea, envolve especificidades concernentes a questões sociais e culturais e é processada mediante conexões neurais. Contudo, é importante ressaltar que metonímia e metáfora são processos distintos. De acordo com Lakoff e Johnson ([1980]2003, p.36), enquanto a metáfora consiste em conceber uma coisa em termos de outra, a metonímia "nos permite usar uma entidade para representar outra. Mas a metonímia não é mero artifício referencial. Ela também cumpre a função de propiciar a compreensão". Portanto, a relação de contiguidade entre as entidades envolvidas na projeção metonímica, conforme a Linguística Cognitiva, não é de natureza meramente estrutural, visto que "sua maior característica reside na possibilidade de se estabelecer conexões entre entidades que coocorrem dentro de uma determinada estrutura conceptual" (DUQUE; COSTA, 2012, p.102). É essa relação que nos permite, por exemplo, ouvir a frase Hoje eu terminei de ler aquele Machado de Assis que ganhei no meu aniversário e compreender que, por Machado de Assis, o falante refere-se a um livro desse autor.

A contiguidade conceptual verificada na metonímia é expressa de modo que uma expressão com significado A sustenta um significado B (LAKOFF; JOHNSON, [1980]2003). Na expressão "precisamos de sangue novo na organização", exemplo da metonímia PARTE PELO TODO, a entidade A "sangue novo" expressa a entidade B "novas pessoas". Lakoff e Johnson ([1980]2003) citam, ainda, as relações metonímicas PRODUTOR PELO PRODUTO ("ele comprou um Ford"), OBJETO USADO PELO USUÁRIO ("precisamos de uma luva melhor na terceira base"), CONTROLADOR PELO CONTROLADO ("Nixon bombardeou Hanoi"), INSTITUIÇÕES PELAS PESSOAS RESPONSÁVEIS ("O Senado considera o aborto imoral"), LUGAR PELA INSTITUIÇÃO ("A Casa Branca não se pronuncia") e LUGAR PELO EVENTO ("O Watergate 
mudou nossa política"). São casos de metonímias chamadas pelos retóricos tradicionais de sinédoques, que, para Lakoff e Johnson ([1980]2003, p.39-40), indicam a sistematicidade das metonímias, ou seja, essas construções não são aleatórias e possuem uma motivação:

$\mathrm{Na}$ verdade, a fundamentação de conceitos metonímicos é, em geral, mais óbvia do que a dos conceitos metafóricos, porque os primeiros, geralmente, envolvem associações físicas ou causais diretas. A metonímia PARTE PELO TODO, por exemplo, emerge das nossas experiências em relação ao modo pelo qual as partes, em geral, estão relacionadas com 0 todo. A metonímia PRODUTOR PELO PRODUTO tem como base a relação de causalidade (e habitualmente física) entre o produtor e seu produto. A metonímia LUGAR PELO EVENTO é fundamentada em nossa experiência com a localização física dos acontecimentos. E assim por diante. [tradução minha]

Pode-se perceber, nos casos supracitados, a ocorrência da estratégia de focalização. $\mathrm{Na}$ metonímia PARTE PELO TODO, por exemplo, destacamos um determinado aspecto de uma entidade porque o consideramos primordial para a compreensão que pretendemos construir. Trata-se da estratégia gestáltica figura-fundo, em que o aspecto focalizado tem status de figura sobre os outros, categorizados como fundo. Essa estratégia, a exemplo de outros mecanismos cognoscitivos, é cultural e socialmente motivada, como podemos concluir a partir do seguinte exemplo:

Se você me pedir para lhe mostrar uma foto do meu filho e eu lhe mostrar uma foto do seu rosto, você ficará satisfeito. Você considerará ter visto uma foto dele. Mas se eu Ihe mostrar uma foto de corpo do meu filho sem seu rosto, você vai estranhar isso e não ficará satisfeito. Você poderá perguntar: "Mas, qual a aparência dele?" Assim, a metonímia O ROSTO PELA PESSOA não é meramente uma questão de linguagem. Em nossa cultura, nós olhamos para o rosto de uma pessoa em vez de sua postura e seus movimentos para termos uma informação básica sobre o que a pessoa é. (LAKOFF; JOHNSON, [1980]2003, p.37) [tradução minha].

Podemos concluir, portanto, que a metonímia deve ser tomada como um fenômeno decorrente não só das experiências físicas, mas, também, atrelado a fatores culturais e sociais, responsáveis pela formação e estabilização dos domínios ativados durante os processos de construção do sentido. Ademais, conforme já sinalizamos e discorreremos mais detalhadamente na sessão a seguir, é um processo que se encontra na base da metáfora.

\section{A conexão entre metonímia e metáfora}

De acordo com Kövecses (2004), é possível dizer que metonímias motivam metáforas. O autor ressalta, especialmente, a existência de uma conexão entre metáforas de emoção e metonímias, no sentido de que estas indicam certos aspectos do corpo que são envolvidos na emoção e que podem ser fatorados em dois tipos: os comportamentais e os fisiológicos. Nesse sentido, por exemplo, pode-se dizer que COMPORTAMENTO SEXUAL ÍNTIMO e COMPORTAMENTO VISUAL AMOROSO são respostas comportamentais que indicam, metonimicamente, amor; já AUMENTO NA FREQUÊNCIA CARDÍACA é um comportamento fisiológico. COMPORTAMENTO VISUAL AMOROSO é específico para amor, enquanto AUMENTO NA FREQUÊNCIA CARDÍACA é geral, na medida em que caracteriza outras emoções além do amor. Tais metáforas baseadas em comportamento, tomadas em conjunto, fornecem um perfil para os conceitos de emoção de nível básico.

Em sendo assim, é plausível pensar na metonímia como fenômeno basilar em termos de construção da figuratividade, posto que ela se encontra na base de conceitos entre os quais costumamos fazer analogias. Taylor (1992) reforça essa compreensão ao afirmar que a metonímia é um dos mais fundamentais processos de extensão de sentido, sendo, talvez, mais básico do que a metáfora e, além disso, presente na raiz de algumas associações metafóricas. Nesse sentido, o autor se refere, especificamente, a trabalhos de Eco (1979, apud TAYLOR, 1992) e Skinner (1957, apud TAYLOR, 1992). Eco supõe que todas as associações são apreendidas, a princípio, como contiguidades que ocorrem dentro de um campo semântico, enquanto Skinner defende que as respostas verbais se generalizam partindo do 
estímulo em direção aos seus atributos mais salientes e, além disso, a entidades que são contíguas ao estímulo. Assim, falar em "olho" como algo que tem os atributos de ser oval e estar próximo ao topo da cabeça facilita a transferência metafórica do olho como órgão da visão para o olho como a abertura de uma agulha. Trata-se de um caso a partir do qual é plausível pensar em metáfora motivada por metonímia; isso não quer dizer, necessariamente, que todas as metáforas se fundamentam em metonímias, mas é possível, a partir desse exemplo, considerar a ideia de que parte das associações metafóricas que construímos pode, sim, ter uma base metonímica.

Essa conexão entre metonímia e metáfora também é observada por Barcelona (2000, apud BARCELONA, 2008), que elenca dois tipos principais de motivação metonímica para associações metafóricas, sobre os quais discorrerei nos próximos parágrafos.

O primeiro tipo é a abstração de uma estrutura conceptual comum entre o domínio-fonte e o domínioalvo que compõem a metáfora. Para exemplificar essa ocorrência, o autor analisa a expressão "That's a loud color", que pode ser traduzida para o português como "essa é uma cor forte", mas, em uma tradução literal, corresponderia a "essa é uma cor alta"; em sendo assim, o enunciado revela um julgamento acerca do tom de uma cor a partir do aspecto do volume de um som, de modo que a metáfora na base da sentença em questão seria CORES DESTOANTES SÃO SONS DESTOANTES (no original, "DEVIANT COLORS ARE DEVIANT SOUNDS"). Essa metáfora seria possibilitada pela abstração de um subdomínio comum, qual seja, o efeito causado tanto por cores destoantes quanto por sons destoantes, "altos", que atraem a atenção de quem os percebe. Segundo Barcelona (2000, apud BARCELONA, 2008, p. 10), "a abstração desse aspecto em comum deve-se à compreensão metonímica prévia das CORES DESTOANTES e dos SONS DESTOANTES (como alvos metonímicos) a partir do seu efeito típico, CAPTURA IRRESISTÍVEL DA ATENÇÃO DA PESSOA QUE PERCEBE A DISSONÂNCIA (como fonte metonímica)".
O outro tipo de motivação metonímica é a generalização ou descontextualização de uma metonímia. Barcelona (2000, apud BARCELONA, 2008) aponta expressões reveladoras da metáfora MAIS É PARA CIMA (como, por exemplo, "ele tem um alto nível de inteligência") como exemplos da descontextualização da metonímia NÍVEL DE VERTICALIDADE PELA QUALIDADE. Essa metonímia é percebida nas frequentes associações feitas em eventos que envolvem coisas sendo amontoadas ou derrubadas, e a descontextualização ocorre sempre que a verticalidade evocada nesses eventos não é, por assim dizer, "literal”. Quando se fala em "alto nível de inteligência", por exemplo, não há um objeto tangível sendo mensurado em termos de verticalidade espacial.

Com base nas considerações aqui apresentadas, conclui-se que há, na base da metáfora, o movimento de focalização de aspectos de determinados domínios antes mesmo da projeção entre o que se constitui como alvo e o que é tomado como fonte. Esse entendimento acerca da motivação metonímica das metáforas é reforçado pela análise e discussão dos dados, que será apresentada após a sessão a seguir, na qual discorremos sobre o corpus e a metodologia adotada para analisá-lo.

\section{Caracterização do corpus e metodologia}

$V$ de vingança é uma narrativa ficcional inspirada na história política da Inglaterra. Quando começou a ser escrita, em 1981, a primeira-ministra da Inglaterra, Margaret Thatcher, implementava o modelo econômico neoliberal e o socialismo entrava em colapso na União Soviética.

Nos quadrinhos, é retratado um futuro distópico: a história começa em 1997, em uma Inglaterra controlada por um governo totalitário, após o fim de um conflito entre países europeus e os Estados Unidos que culmina com um ataque nuclear pelos EUA. Embora não tenha sido bombardeada, a Inglaterra acaba sofrendo grandes prejuízos. Por causa das explosões, o clima é afetado a ponto de o continente europeu quase sumir em decorrência das 
inundações. Além de plantações terem sido destruídas, o país para de receber comida porque não há mais quem a forneça. Além disso, muitas pessoas adoecem e morrem em decorrência do transbordamento de esgotos. Nesse cenário, o governo se desmonta, quadrilhas armadas tentam tomar o poder e, na sequência, grupos fascistas e as grandes corporações sobreviventes ao conflito nuclear formam uma coalizão denominada Nórdica Chama, que é eleita e mantida no poder por uma população apática. Após quatro anos de regime opressor - incluindo o controle dos meios de comunicação, a repressão a qualquer tentativa de protesto e o envio de radicais, negros, estrangeiros e homossexuais a um campo de concentração, denominado "campo de reabilitação de Larkhill" -, surge um homem que se identifica apenas como V. Ele usa uma máscara que lembra as feições de Guy Fawkes, soldado inglês que, em 1605, foi condenado à morte por ter participado de uma conspiração para assassinar o Rei James I e todos os parlamentares ingleses explodindo o parlamento britânico com 36 barris de pólvora. Inspirado na figura de Fawkes, V assume uma postura anarquista e pratica atos como a explosão de prédios do governo e a execução de colaboradores do governo e ex-funcionários de Larkhill. Numa dessas ações, V salva da morte Evey Hammond, uma órfã de 16 anos que logo é acolhida por ele e passa a ser tratada como aprendiz. No lar de V, chamado por ele de "Galeria das Sombras", a garota, além de ser apresentada a um acervo cultural remanescente do período anterior ao conflito político, também se torna cúmplice do seu mentor.

Em sendo uma história em quadrinhos, $V$ de vingança fornece, como guias para o leitor no processo de construção de sentidos para a história, pistas advindas não só dos mecanismos verbais como também dos não verbais. Sobre isso, Eisner $(2001 ; 2008)$ e McCloud $(2005 ; 2008)$ ressaltam que a relação entre a estrutura dos quadrinhos e o efeito que ela provoca sobre o leitor envolve mais do que a decodificação dos textos postos dentro dos balões e as impressões sobre as representações gráficas de personagens e de cenários.
Quanto à configuração do texto verbal nas $\mathrm{HQ}$, diversas fontes podem ser utilizadas nos textos escritos no interior dos balões e dos quadros, dependendo da intenção do autor quanto à representação do tom e do volume de voz dos personagens, de modo que o leitor possa "ouvir com os olhos" (MCCLOUD, 2008, p.146). Com relação ao não verbal, elementos básicos como as sarjetas (linhas que separam os quadros), os requadros (linhas que demarcam o limite dos quadros), as fontes utilizadas nos textos, os espaçamentos entre os quadros, os formatos dos balões, as características e expressões faciais e gestuais dos personagens, entre outros, podem funcionar como pistas de modo que 0 leitor construa sentidos para a história. $\bigcirc$ enquadramento de certos detalhes da ação, por exemplo, "não só define seu perímetro, como estabelece a posição do leitor em relação à cena e indica a duração do evento" (EISNER, 2001, p.25).

Esses não são os únicos elementos a comporem o mosaico de pistas que constitui as histórias em quadrinhos; há outros recursos muito eficientes no que diz respeito à ativação das capacidades cognitivas do leitor, embora nem sempre eles sejam perceptíveis quando da(s) primeira(s) leitura(s). Eisner (2001; 2008) e McCloud (2005; 2008) apontam a importância do trabalho minucioso com a caracterização dos personagens de modo a conquistar o leitor, mediante a evocação de suas experiências e suas emoções. Afinal, quanto maior a identificação do leitor com a história, maior seu envolvimento.

Nesse sentido, a ativação do repertório cultural pode exercer grande influência sobre a pessoa que lê uma história, a ponto de permitir a construção de inferências que acabam tendo grande participação no processo de construção da figuratividade. Em $V$ de vingança, por exemplo, há uma evocação frequente do conhecimento de mundo do leitor acerca de situações de perseguição e opressão. Afinal, trata-se de uma história cujo cenário é, basicamente, o da capital de um país que sofre as consequências de uma guerra entre outras nações e é subjugado por um governo totalitário, contra o qual se insurge um 
homem que, dependendo da perspectiva, pode ser um herói que luta contra a repressão, um terrorista que quer se vingar do sistema que o aprisionou em um campo de concentração ou, simplesmente, um anarquista em busca da reconfiguração total de uma cidade vitimada pela opressão de um governo totalitário.

Esses aspectos são levados em conta na análise à qual procedemos a seguir. Ela tem cunho qualitativo, pois analisamos os dados com o objetivo de mostrar os mapeamentos que subjazem à metáfora e à metonímia construídas durante a leitura do fragmento selecionado, de modo a esclarecer as relações entre os domínios ativados durante a leitura integrada dos mecanismos verbais e dos recursos não verbais de $V$ de vingança. Como o objetivo é focalizar a leitura integrada de textos de naturezas distintas, possíveis metáforas e metonímias ancoradas apenas no texto verbal ou no não-verbal não foram consideradas.

\section{Análise e discussão}

Antes de iniciar a análise do fragmento reproduzido na figura 1, é importante contextualizá-lo, de modo que a sustentar parte da discussão que se ancoram não só no dado escolhido bem como em outras passagens de $V$ de vingança que influenciam na construção da metáfora e da metonímia a serem evidenciadas.

$\mathrm{Na}$ cena retratada na figura 1 , Evey e V dançam juntos na Galeria das Sombras, o lar dos dois. Trata-se da parte final de uma sequência em que é narrada a transformação de Evey. Abandonada por $\mathrm{V}$ após se revoltar com o fato de ter colaborado com uma ação do anarquista que culminou na morte de um bispo, ela é resgatada por um civil chamado Gordon, que se torna seu amante. Dois meses após os dois personagens iniciarem a relação amorosa, Gordon é morto por agentes do governo. Revoltada, Evey se apropria de uma arma de fogo que estivera guardada pelo amante e resolve seguir um dos executores de Gordon com o intuito de matá-lo, mas acaba sendo surpreendida e capturada por um homem cuja identidade não é revelada. Na prisão, a moça é torturada e interrogada, durante vários dias, sobre o paradeiro de V. Nesse período, seu único consolo é uma carta encontrada dentro de sua cela e escrita em um pedaço de papel higiênico por uma atriz chamada Valerie Page, presa e morta anos antes por ser homossexual. Um dia, Evey recebe 0 comunicado de que será executada, a menos que confesse onde está V. Ao dizer que prefere morrer, a moça é libertada e descobre que, na verdade, a prisão e a tortura que sofreu foram encenadas pelo próprio $\mathrm{V}$ com o pretexto de torná-la livre de seus medos. A princípio, Evey sente ódio, mas logo percebe que está mais madura e forte do que antes de ser "presa" e passa a demonstrar gratidão a ele. Nesse ínterim, $V$ revela que a carta de Valerie era real e lhe fora entregue pela própria atriz enquanto ambos estavam presos no campo de concentração de Larkhill anos atrás. Após a revelação, ele mostra a Evey um jardim no qual cultiva rosas vermelhas em memória de Valerie. Essas são, inclusive, as flores envenenadas que $\mathrm{V}$ utiliza para matar algumas das pessoas de quem busca se vingar. Na ocasião, Evey recusa a oferta por parte do seu parceiro de colher uma das rosas para matar o executor de Gordon. Em seguida, os dois dançam na Galeria das Sombras, conforme pode ser visto na figura 1 .

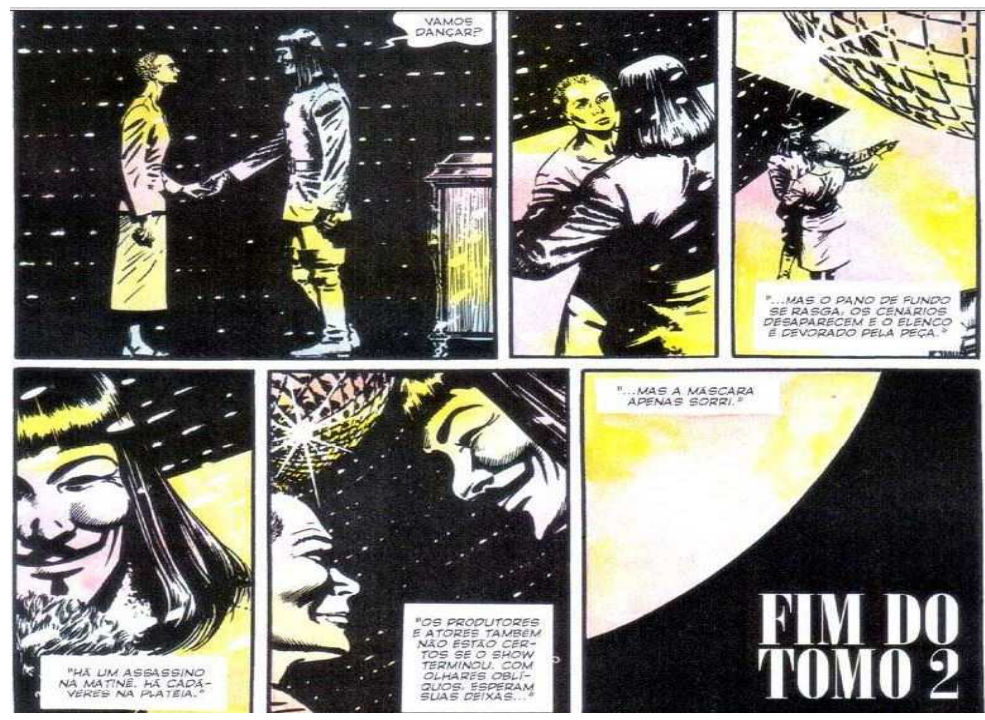

Figura 1: Fragmento de $V$ de Vingança. Fonte:

MOORE; LLOYD (2006, p. 181).

No fragmento analisado, o foco em algumas partes dos corpos e das faces de Evey e de $\mathrm{V}$ e, 
também, em poucos detalhes da Galeria das Sombras estimula o leitor a simular o todo, ou seja, o que resta em termos de configuração física dos personagens e do ambiente em que estão. Um processo similar ocorre quando o leitor, à medida que é apresentado a um pano de fundo, um cenário, um elenco, a realização de uma matinê e a presença de plateia, produtores e elenco, é capaz de, por meio dessas partes, construir um todo composto pelo conjunto desses itens, comumente associados a espetáculos teatrais.

Há de se perceber, ainda, que o leitor tende a voltar sua atenção a elementos que são focalizados em detrimento de outros que também poderiam compor a cena graficamente representada. Na figura 1, por exemplo, o foco é mantido nos personagens que dançam, de modo que os móveis e a decoração da Galeria das Sombras se tornam periféricas. O casal dançando é o elemento em maior evidência até o quarto quadrinho, no qual o rosto de $V$ é focalizado. Nesse momento, vale ressaltar o texto verbal, que, no quadrinho em questão, faz saber que "Há um assassino na matinê. Há cadáveres na platéia [sic]". A sobreposição desse excerto ao rosto de $\mathrm{V}$ pode fazer com que o leitor compreenda que o anarquista é o assassino, percepção que é reforçada pelo fato de que, desde $\mathrm{o}$ início da história, $\mathrm{V}$ comete assassinatos para eliminar componentes e simpatizantes do governo dos quais deseja se vingar. Um processo semelhante pode ocorrer no quinto quadrinho, em que "os produtores e atores" podem ser associados pelo leitor a Evey e V, posto que ambos têm os rostos focalizados e, além disso, sorriem e se olham ao mesmo tempo em que o balão que acompanha o quadrinho exibe o texto verbal "com olhares oblíquos, esperam suas deixas".

Ao serem focalizados no centro de três quadrinhos da figura 1 e enquadrados, juntos, como os "produtores e atores" do ato teatral/anárquico, os personagens Evey e $\mathrm{V}$ podem ser conceptualizados como elementos que se encontram na categoria de mentores e principais executores das ações de anarquia. Ademais, há uma analogia entre ANARQUIA e ESPETÁCULO TEATRAL de tal modo que podem ser percebidos como categorias análogas, a ponto de a primeira ser conceptualizada em termos da segunda. Trata-se da seguinte operação: dois domínios entre os quais há atributos similares são mapeados em um circuito metafórico por meio das ligações entre entidades que os compõem. Além disso, há de se considerar a possibilidade de, a partir de elementos tais como pano de fundo, plateia, matinê, elenco, perceber que existe um ato e, em seguida, compreender que sua magnitude decorre não só desses elementos por si, mas, principalmente, da relação de tal ato com o TODO do qual faz parte: um ESPETÁCULO promovido por V e Evey.

Nesse sentido, destaca-se que, a relação entre ATO e ESPETÁCULO, há uma espécie de gradação, de maneira que ATO, dentro da ESCALA na qual se inserem as atividades de Evey e $\mathrm{V}$, é menor do que o ESPETÁCULO criado e protagonizado por eles. Em sendo assim, existe, entre ATO e ESPETÁCULO, uma relação metonímica. Concomitantemente, pode ser construída a concepção de que ANARQUIA maior motivadora dos atos dos personagens em questão - e ESPETÁCULO - domínio a partir de cujos elementos se conceptualizado o caráter das 102 Jos anarquistas - são categorias análogas, posto que há, nelas, atributos entre os quais se estabelecem mapeamentos metafóricos, conforme será descrito em breve.

Há de se observar, ainda, a influência de pistas do cenário, entendido como um conjunto de elementos que permite reconhecer um lugar como tal. Nesse sentido, o domínio ESPETÁCULO TEATRAL é construído por meio das pistas contidas nos balões a partir do terceiro quadrinho, nos quais se lê: "'mas o pano de fundo se rasga, os cenários desaparecem e o elenco é devorado pela peça. Há um assassino na matinê. Há cadáveres na platéia [sic]. Os produtores e atores também não estão certos se o show terminou. Com olhares oblíquos, esperam suas deixas...". Existem, nesse excerto, pistas que remetem diretamente ao universo teatral, tais como "pano de fundo", "cenários", "elenco", "peça", "matinê", "plateia". Trata-se de partes que acabam funcionando como gatilhos para a construção do todo 
que vem a ser o cenário do ESPETÁCULO TEATRAL.

Ocorre, porém, que há uma particularidade quanto a esse domínio: o leitor pode ser guiado a pensar em termos de um espetáculo não prototípico, por assim dizer. Afinal, em vez de o pano de fundo ser mantido para funcionar como complemento cenográfico ou, simplesmente, ser retirado em decorrência do encerramento da peça, ele se rasga; em vez de o elenco atuar, é devorado pela peça; em vez de se divertir, o público da matinê é assassinado. Cabe, aqui, chamar a atenção para o fato de itens lexicais como "rasgar", "desaparecer" e "devorar" direcionarem o leitor a simular um cenário de desordem e de violência, a ponto de os produtores e atores - considerando que, em sendo atores, fazem parte do elenco - também correrem o risco de ser devorados pelas ações que praticam, o que só evidencia a violência do sistema.

Nesse sentido, cabe ressaltar a importância da focalização de determinados elementos não verbais na porção inferior da figura. No quarto quadrinho, em cujo balão se lê "'Há um assassino na matinê'”, é evidenciado o rosto de V. É possível, a partir da organização dessas pistas e, também, do fato de esse personagem já ter matado pessoas até esse ponto da história, o leitor compreender que o "assassino" é V. Um processo similar pode ocorrer no quinto quadrinho, em que se sobrepõe, à imagem dos rostos de Evey e V, o seguinte texto verbal: "os produtores e atores também não estão certos se o show terminou. Com olhares oblíquos, esperam suas deixas...". Logo depois, no último quadrinho, lê-se que "a máscara apenas sorri". O leitor pode compreender que os "produtores e atores" do espetáculo são Evey e V, posto que as referidas pistas verbais se sobrepõem a uma imagem na qual se focalizam os dois personagens, ambos sorridentes e com olhares oblíquos. Além disso, ambos, em especial V, orquestram e promovem ações anarquistas na cidade de Londres. Em sendo assim, são os "produtores e atores" do "espetáculo" que ocorre na capital inglesa desde o início da obra.

Essas analogias feitas a partir da leitura dos últimos quadrinhos reforçam a construção da metáfora ANARQUIA É ESPETÁCULO TEATRAL, que pode ser considerada o ponto de culminância de um processo que se desenrola ao longo de $V$ de vingança. Afinal, no ponto da história em que se encontra o fragmento analisado, o leitor já sabe que $\mathrm{V}$ - o qual se torna uma espécie de mentor de Evey se diz amante da anarquia e que essa é a linha que orienta a sua empreitada contra as pessoas que, direta ou indiretamente, são ou foram responsáveis pela situação em que Londres se encontra e por todos os desmandos cometidos pelo governo da cidade. Essa afirmação é feita no segundo quadrinho do excerto reproduzido na figura 2 , retirado da sequência em que $\mathrm{V}$ discursa, sozinho, diante do Tribunal Central Criminal da Inglaterra, vulgarmente conhecido como Old Bailey, no topo do qual há uma estátua que representa a Justiça:
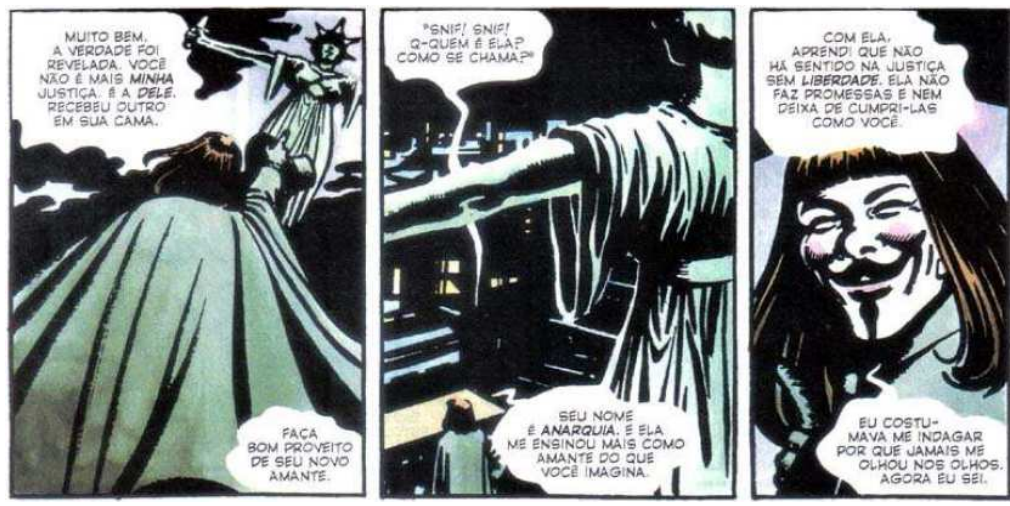

Figura 2: Fragmento de $V$ de vingança. Fonte: MOORE; LLOYD (2006, p. 43).

Também há referência à anarquia na primeira página após a capa de $V$ de vingança. $O$ símbolo do personagem, reproduzido por $\mathrm{V}$ em alguns dos locais em que fez vítimas, assemelha-se ao símbolos da anarquia, conforme visto na figura 3 : 

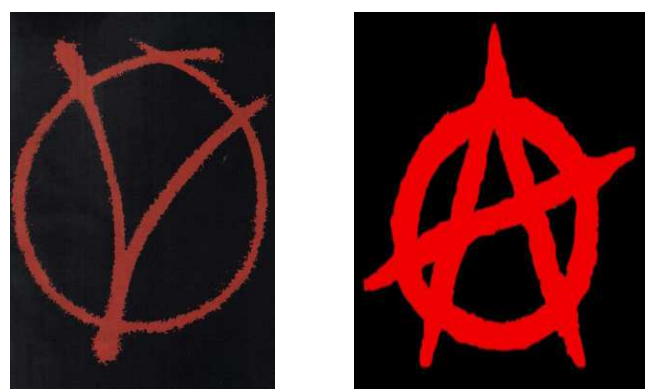

Figura 3: Símbolos de $\mathrm{V}$ e da anarquia. Fontes: MOORE; LLOYD (2006, p.2) e ESSE BLOG É PUNK (acesso em 2014).

Além das referências claras à anarquia como orientadora das ações de $\mathrm{V}$, há menções, feitas pelo próprio personagem, ao caráter teatral da sua atuação. Enquanto orquestra e pratica suas ações anarquistas, V costuma entoar canções e citar trechos de obras literárias que se relacionam, de algum modo, com a história da pessoa a ser executada ou do monumento ou prédio a ser destruído. Em uma de suas ações, que culmina com o sequestro e a tortura psicológica do radialista Lewis Prothero, V monta um cenário no cômodo da Galeria das Sombras onde prendeu sua vítima e, além disso, usa uma indumentária diferente das roupas e da máscara costumeiras, tudo minimamente pensado com o objetivo de causar sofrimento psicológico a Prothero. $\mathrm{O}$ início dessa sequência, na qual o próprio $V$ faz referência a aspectos do teatro e ao fato de ele e Evey serem protagonistas de "um verdadeiro drama" em que estão "contra o mundo", pode ser observado na figura 4:
A relação entre os domínios ANARQUIA e ESPETÁCULO TEATRAL também é sustentada por verbos que, mais do que ativar o domínio ESPETÁCULO TEATRAL, evidenciam a desordem e a violência que permeia a ANARQUIA norteadora das ações de V. Em sendo assim, pode-se dizer que "rasgar", "desaparecer" e "devorar" estão no cerne da figuratividade construída a partir da leitura do fragmento em tela. Ocorre que esses verbos não podem ser tomados como indicadores de ações isoladas. De fato, os três estão interligados, considerando-se que compõem, juntos, o Cenário construído pelo leitor que os relaciona, concomitantemente, a ESPETÁCULO TEATRAL e a 104 UIA. Considerando-se a natureza desses domínios e a relação que entre eles se estabelece, é possível afirmar que as ações de rasgar o pano de fundo, fazer os cenários sumirem e devorar o elenco estão, na verdade, na base de uma ação ainda mais abrangente, que está na base da ação de "encenar". Afinal, a metonímia e a metáfora construídas ancoram-se em uma relação entre anarquizar e teatralizar, conforme já observado.

Assim, percebe-se a motivação metonímia de ANARQUIA É ESPETÁCULO TEATRAL de modo que há um realce das partes - a saber, as ações correspondentes ao desenrolar do ato encenado que constituem 0 todo - o espetáculo. A compreensão se dá, em parte, em decorrência de pistas anteriormente apresentadas; tais pistas levam a uma compreensão global de todas as cenas
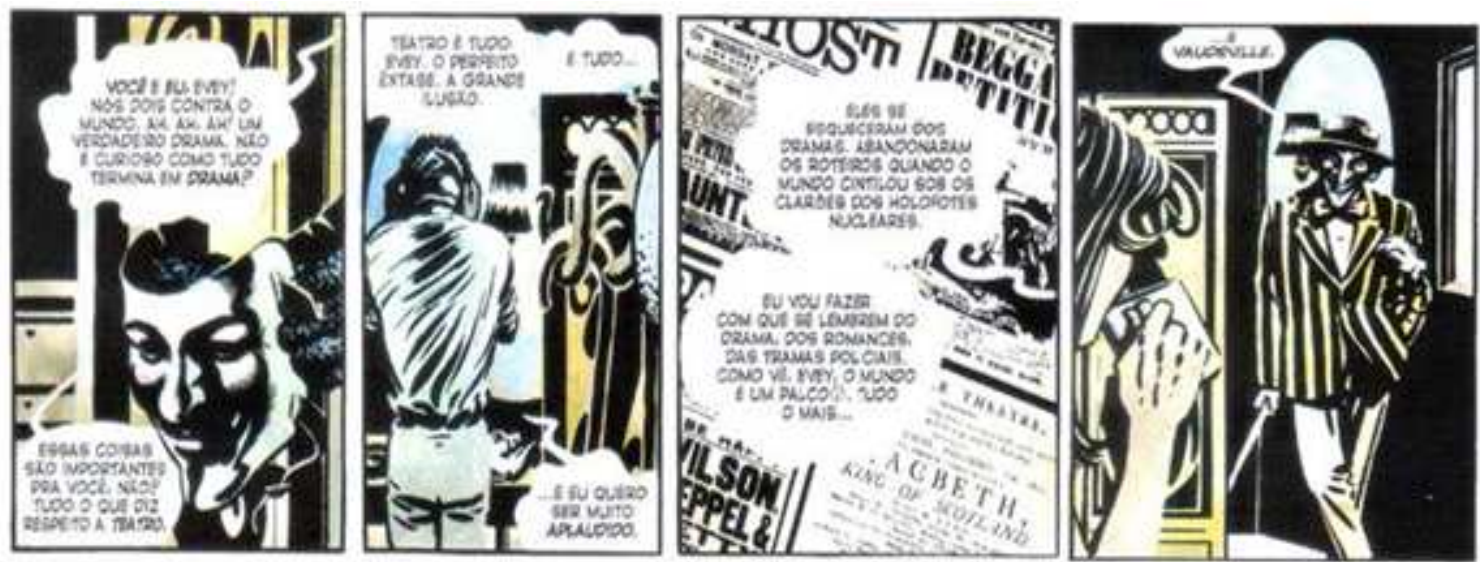

elaboradas por $\mathrm{V}$ para dar vazão à arte, por meio das situações que encena de modo teatral, ao mesmo tempo em que explode monumentos

Figura 4: Fragmento de V de vingança. Fonte: MOORE; LLOYD (2006, p. 33). e mata pessoas. Em sendo assim, a compreensão desse cenário mais amplo é fundamental para que se 
compreenda o que é o "ato" descrito. Assim, pode-se afirmar que a PARTE - o ato - é compreendida em termos do TODO - o espetáculo teatral. Nesse sentido, há uma relação de contiguidade em que ATO desempenha o papel semântico da PARTE, e ESPETÁCULO, o do TODO.

Com relação à metáfora ANARQUIA É ESPETÁCULO TEATRAL, verifica-se o mapeamento entre domínios apresentado no quadro 1

METÁFORA: ANARQUIA É ESPETÁCULO TEATRAL

\begin{tabular}{|c|c|}
\hline $\begin{array}{c}\text { DOMÍNIO ESPETÁCULO } \\
\text { TEATRAL }\end{array}$ & DOMÍNIO ANARQUIA \\
\hline atos do espetáculo & ações anarquistas \\
\hline elenco & anarquistas \\
\hline plateia & vítimas \\
\hline
\end{tabular}

Quadro 1: Estrutura básica da metáfora ANARQUIA É ESPETÁCULO TEATRAL. Fonte: autoria própria.

As ligações entre esses atributos se estabelecem de modo a permitir as projeções listadas no quadro 2:

\section{ANARQUIA É ESPETÁCULO TEATRAL}

Ações anarquistas são Atos do espetáculo

Anarquistas são Elenco

\section{Vítimas são Plateia}

Quadro 2: projeções metafóricas de ANARQUIA É ESPETÁCULO TEATRAL Fonte: autoria própria.

Encerrada a análise dos dados, apresento, na sessão a seguir, considerações de caráter mais geral acerca da discussão já apresentada.

\section{Conclusão}

A análise empreendida revela que, a partir da leitura integrada dos recursos gráficos e do texto verbal que compõem o fragmento analisado de $V$ de Vingança, é possível construir uma metáfora, metonimicamente motivada, que revela a concepção de ANARQUIA em termos de um ESPETÁCULO TEATRAL, bem como o movimento de focalização de PARTES desses domínios a partir das quais é possível compreender o TODO correspondente ao domínio-alvo.

De fato, uma vez que apenas alguns atributos dos domínios mapeados são associados durante a leitura, não há como pensar em metáfora que não seja metonimicamente motivada, posto que o leitor é levado - inclusive pela maneira como se organizam certos recursos gráficos - a focalizar alguns detalhes que levam a determinada construção metafórica, a qual pode revelar uma visão de mundo que norteie a narrativa.

Ademais, a compreensão de que há similaridades nos processos de construção da linguagem em decorrência de eles se fundamentarem nas mesmas vivências que experienciamos enquanto seres dotados de certa configuração física e participantes de determinadas práticas sociais e culturais é suficiente para se concluir que os processos envolvidos na construção de metáforas e metonímias são os mesmos.

Cabe, porém, lembrar que, embora ensejadas pelos mesmos mecanismos mentais, metáfora e metonímia são processos diferentes. Na metáfora há, necessariamente, a presença de dois domínios distintos, um de natureza mais concreta e outro de natureza mais abstrata; esses domínios contêm atributos entre os quais ocorrem mapeamentos, de modo que o domínio mais abstrato é conceptualizado em termos do mais concreto. Já a metonímia se caracteriza pela relação assimétrica (em que um atributo é identificado em termos de características do outro) entre dois atributos que fazem parte de um único domínio.

O fato é que, independentemente da modalidade linguística, construímos metáforas e metonímias a partir não só das pistas que se nos apresentam bem como do conhecimento prévio acerca de questões socioculturais ativadas pelo texto lido. 


\section{REFERÊNCIAS}

BARCELONA, Antonio. Metonymy is not just a lexical phenomenon: on the operation of metonymy in grammar and discourse. In: ALM-ARVIUS, Christina; JOHANNESSON, Nils-Lennart; MINUGH, David. (eds.). Selected Papers from the Stockholm 2008 Metaphor Festival. Stockholm: Stockholm UP, 2008, p. 1-40.

EISNER, Will. Quadrinhos e arte sequencial. São Paulo: Martins Fontes, 2001.

Narrativas gráficas: princípios e práticas da lenda dos quadrinhos. São Paulo: Devir, 2.ed, 2008.

ESSE BLOG É PUNK. Disponível em: $<$ http://esseblogepunk.blogspot.com.br/2010/04/co mportamento.html>. Data de acesso: 200914.

KÖVECSES, Zoltán. Metaphor and emotion: language, culture, and body in human feeling. Cambridge: Cambridge University Press, 2004.

LAKOFF, George; JOHNSON, Mark. Metaphors we live by. Chicago: The University of Chicago Press, [1980]2003.

Philosophy in the flesh: the embodied mind and its challenge to western thought. New York: Basic Books, 1999.

MCCLOUD, Scott. Desvendando os quadrinhos. São Paulo: M. Books do Brasil, 2005.

Desenhando quadrinhos. São Paulo: M. Books do Brasil, 2008.

MOORE, Allan; LLOYD, David. V de vingança. Rio de Janeiro: Panini, 2006.

\section{COMO CITAR ESSE ARTIGO}

SOUSA, Ada Lima Ferreira de. A construção metafórica e metonímica da anarquia na história em quadrinhos $\mathrm{V}$ de Vingança. Signo, Santa Cruz do Sul, v. 44, n. 79, jan. 2019. ISSN 1982-2014. Disponível em: <https://online.unisc.br/seer/index.php/signo/article/view/12700>. Acesso em: https://doi.org/10.17058/signo.v44i79.12700. 